\title{
Reproductive Biology of the Striped Seabream
}

\section{Lithognathus mormyrus (Linnaeus, 1758) from Al Haneah Fishing Site, Mediterranean Sea, Eastern Libya}

\author{
Eyman Faraj Abd Alssalam ${ }^{1}$, Sayed Mohamed Ali ${ }^{1}$, Mohammad El Sayed El Sayed El Mor ${ }^{1,2}$, Ramadan Attea \\ Saleh $\mathrm{Ali}^{1}$ and Eman Salem Al Fergani ${ }^{1}$ \\ 1. Department of Zoology, Omar Al-Mukhtar University, Al Beida, Libya \\ 2. Department of Science, Suez Canal University, Egypt
}

\begin{abstract}
Reproductive biology of L. mormyrus was studied using monthly samples totaling 224 fish obtained from Al-Haneah fishing site, eastern Libya Mediterranean Sea. Lengths of the examined fish ranged between $11.5 \mathrm{~cm}$ and $23.4 \mathrm{~cm}$. Corresponding weights were $24.5 \mathrm{gm}$ and $160.8 \mathrm{gm}$. The minimum values of the condition factors, $\mathrm{K}_{\mathrm{F}}$ and $\mathrm{K}_{\mathrm{C}}$, were 1.38 and 1.21 at the average fish length of $12.4 \mathrm{~cm}$. These values increased with increases in length until they reached maximum values of 1.59 and 1.41 at the length of $22.1 \mathrm{~cm}$. The high values of $\mathrm{K}_{\mathrm{F}}$ and $\mathrm{K}_{\mathrm{C}}$, Gonado-Somatic Index and oocyte diameter maintained during May, June, July, and August and the monthly changes in gonadal condition, indicated that summer was the breeding season of L. mormyrus. The oocyte diameter ranged between $379 \pm 25.3 \mu$ and $1,511 \pm 143.3 \mu(\mathrm{n}=76)$ with an average of $895 \pm 111.3 \mu$. The sex ratio was in favor of females during all months of the study. The overall sex ratio was $1: 1.52$. Length at first maturity, $\mathrm{L}_{50}$, for $L$. mormyrus was found to be $14.15 \mathrm{~cm}$ for males and 14.45 for females. Overall average of absolute fecundity was $4,342 \pm 557$ egg per fish $(n=45)$. The overall average of relative fecundity was $234 \pm 181$ egg per $\mathrm{cm}$. Absolute fecundity increased with increasing fish length.
\end{abstract}

Key words: Reproductive biology, length at first maturity, oocyte diameter, fecundity, striped Seabream, Lithognathus mormyrus.

\section{Introduction}

Lithognathus mormyrus [1], striped Seabream or sand steenbras, family Sparidae, is a marine gregarious demersal fish inhabiting sandy shallow coastal waters. It is commonly not more than $30 \mathrm{~cm}$ long [2, 3]. It feeds on worms, mollusks, small crustaceans and detritus. It is protandrous hermaphrodite and breeds in summer (Russell et al., 2014). The fish is subtropical, widely distributed in the eastern Atlantic Ocean, the Mediterranean sea, the Red sea and the southwestern Indian Ocean. In Libya it is present along the whole coast and is common in the artisanal catch [4]. The IUCN status of this fish is: Least concern.

Corresponding author: Sayed Mohamed Ali, professor, Dr., research fields: oceanography, fisheries, chemistry, zoology and environment.
The objective of the present work was to study reproductive biology of L. mormyrus obtained from the artisanal catch of Al-Haneah, eastern Libya Mediterranean Sea. The data obtained will be helpful in managing the fisheries of this fish in Libya.

\section{Methods}

\subsection{AL-Haneah Fish Landing Site}

Al-Haneah and vicinity (Fig. 1) is a principal fishing ground on eastern Libyan Mediterranean Sea. L. mormyrus is common in its artisanal catch.

\subsection{The Reproductive Biology Studies}

These were the condition factors, the gonado-somatic index, the maturity stages, the length at first maturity, the sex ratio, the breeding season, fecundity and eggs diameter. 


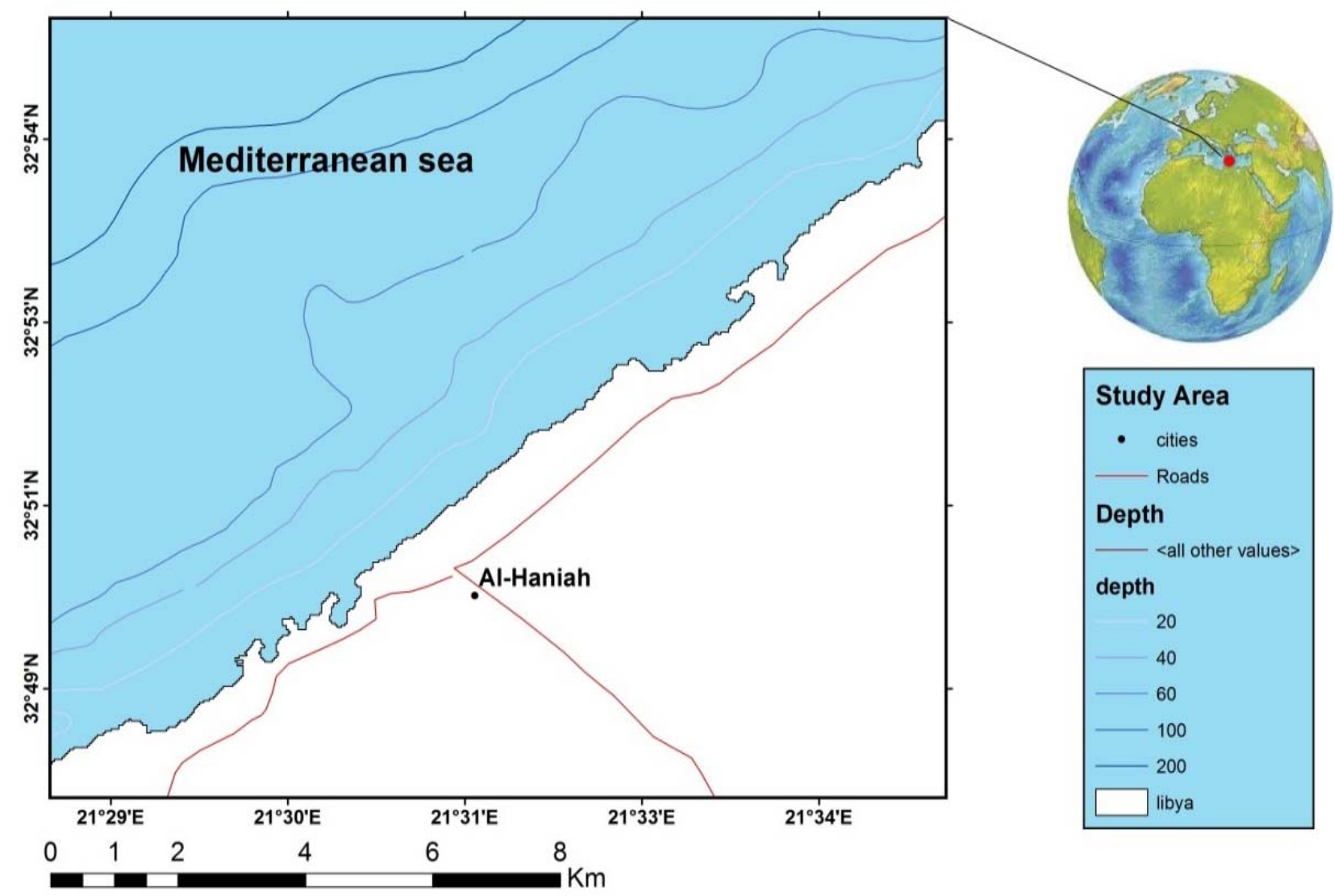

Fig. 1 Al-Haneah fishing site.

\subsubsection{Collection and Treatment of L. mormyrus} samples

An average of 19 L. mormyrus were collected monthly from Al-Haneah artisanal catch during March 2015 to February 2016 for use in the biological studies. Altogether 224 fish were used. The monthly samples were brought to the Marine Laboratory of the Zoology Department of Omar Al-Mukhtar University. For each fish total length and corresponding weight were measured to the nearest $\mathrm{mm}$ and the first decimal of the gram. The abdominal cavity was then cut open with a scissor and the condition of the ovary (maturity stages) according to El-Ganainy and Buxton [5] was observed and recorded. The gonads were then taken out and weighed, ovaries with well-developed eggs were preserved in $10 \%$ formalin for later reading the oocyte diameter under the low power of a microscope fitted with an eye piece micrometer. Corresponding eviscerated fish weights were recorded.

\subsubsection{The Condition Factor}

Monthly Fulton's and Clark's condition factors (" $\mathrm{K}_{\mathrm{F}}$ ", " $\mathrm{K}_{\mathrm{C}}$ ") for female and male L. mormyrus were obtained monthly according to Froese and Bagenal and Tesch $[6,7]$.

$\mathrm{K}_{\mathrm{F}}=100\left(\mathrm{~W} / \mathrm{L}^{3}\right) \ldots$ Fulton's condition factor.

$\mathrm{K}_{\mathrm{C}}=100\left(\mathrm{EW} / \mathrm{L}^{3}\right) \ldots$ Clark's condition factor.

$\mathrm{W}$ : whole fish weight in grams

EW: eviscerated fish weightin grams

L: fish length in centimeters

The factor 100 was used to bring K close to unity.

2.2.3 Gonado-Somatic Index (GSI)

GSI was determined monthly according to Anderson and Gutreuter and Akter et al. [8,9].

$\mathrm{GSI}=100 \mathrm{wt}$ of gonad $(\mathrm{gm}) / \mathrm{wt}$ of whole fish (gm)

GSI: Gonado-somatic index

wt: weight 


\subsubsection{Maturity Stages}

These were recorded monthly as I: immature, II: developing, III: mature, IV: regressing, V: regenerating [5].

\subsubsection{Length at First Maturity $\left(\mathrm{L}_{50}\right)$}

$\mathrm{L}_{50}$, the length at which $50 \%$ of individuals were mature, was obtained by plotting the percentage mature fish in each length class of the whole population versus length. From the curve, $\mathrm{L}_{50}$ was the length corresponding to $50 \%$ mature.

\subsubsection{Sex Ratio}

Sex ratio was determined by counting the number of males and females in the monthly samples studied.

\subsubsection{The Breeding Season}

The breeding season was established from analysis of the monthly variation in the condition factor, the GSI and the maturity stages.

\subsubsection{Fecundity}

Total or absolute fecundity (TF) is the total number of eggs in the ovaries of a fish prior to spawning [10]. In the present study mature ovaries were removed from their fish and placed in 10\% formalin for one day to allow the eggs to harden. Each ovary was then taken out of the formalin, dried with a tissue paper and weighed. Three small sub samples were taken from the front, mid and rear parts of the ovary, weighed and atomized by rubbing gently with fingers.

The number of eggs in each sub sample was counted under the low power of a microscope. The number of eggs in the ovary based on each sub sample was calculated as:

Number of eggs in the ovary $=\mathrm{OW}(\mathrm{gm}) / \mathrm{SW}(\mathrm{gm})$

*NS [7] OW: ovary weight (gm)
SW: sub sample weight (gm)

NS: total number of eggs in sub sample.

Total fecundity was then obtained by averaging the numbers of eggs per ovary calculated from each of the three sub samples.

Relative fecundity (RF) is the number of eggs per unit length $(\mathrm{cm})$ or the number of eggs per unit weight (g) of fish. To estimate relative fecundity individual fecundities were divided by corresponding lengths or weights [11].

\subsubsection{Egg Diameter}

The egg diameter $(\mu)$ was established monthly with aid of a microscope fitted with an eye piece micrometer. Each month individual dimeters of 10 non deformed and rounded oocytes taken from different parts of ovaries of individual females were measured under the low power of the microscope. The average diameter was then calculated.

\section{Results}

\subsection{Lengths, Corresponding Weights, and Condition Factors}

In the present study fish lengths ranged between 11.5 $\mathrm{cm}$ and $23.4 \mathrm{~cm}$. Corresponding weights were $24.5 \mathrm{gm}$ and $160.8 \mathrm{gm}$. All fish lengths were divided into 6 length classes with class range of $1.9 \mathrm{~cm}$ as shown in Table1.

The minimum values of the condition factors $\mathrm{K}_{\mathrm{F}}$ and $\mathrm{K}_{\mathrm{C}}$ were 1.38 and 1.21 at the average observed length of $12.4 \mathrm{~cm}$ (Table 1 and Fig. 2). These values increased with increases in length until they reached maximum values of 1.59 and 1.41 at the maximum observed length of $22.1 \mathrm{~cm}$.

Table 1 Fish lengths, weights and condition factors $\left(K_{F}\right.$ and $\left.K_{C}\right)$, per length class range of 224 L. mormyrus from Al-Haneah coast. Number of fish within each class range is given between two brackets.

\begin{tabular}{lllll}
\hline Length class range $\mathrm{cm}$ & Average length $\mathrm{cm}$ & Average weight gm & $\mathrm{K}_{\mathrm{F}} \pm$ S.D. & $\mathrm{K}_{\mathrm{C}} \pm \mathrm{S} . \mathrm{D}$. \\
\hline $11.5-13.4(39)$ & 12.4 & 24.5 & $1.38 \pm 0.71$ & $1.21 \pm 0.56$ \\
$13.5-15.4(37)$ & 14.3 & 39.7 & $1.44 \pm 0.99$ & $1.24 \pm 0.76$ \\
$15.5-17.4(34)$ & 16.2 & 59.2 & $1.49 \pm 1.02$ & $1.29 \pm 0.95$ \\
$17.5-19.4(41)$ & 18.3 & 83.7 & $1.55 \pm 1.09$ & $1.32 \pm 0.99$ \\
$19.5-21.4(40)$ & 20.5 & 133.5 & $1.57 \pm 1.11$ & $1.34 \pm 1.01$ \\
$21.5-23.4(33)$ & 22.1 & 160.8 & $1.59 \pm 1.20$ & $1.41 \pm 1.08$ \\
\hline
\end{tabular}




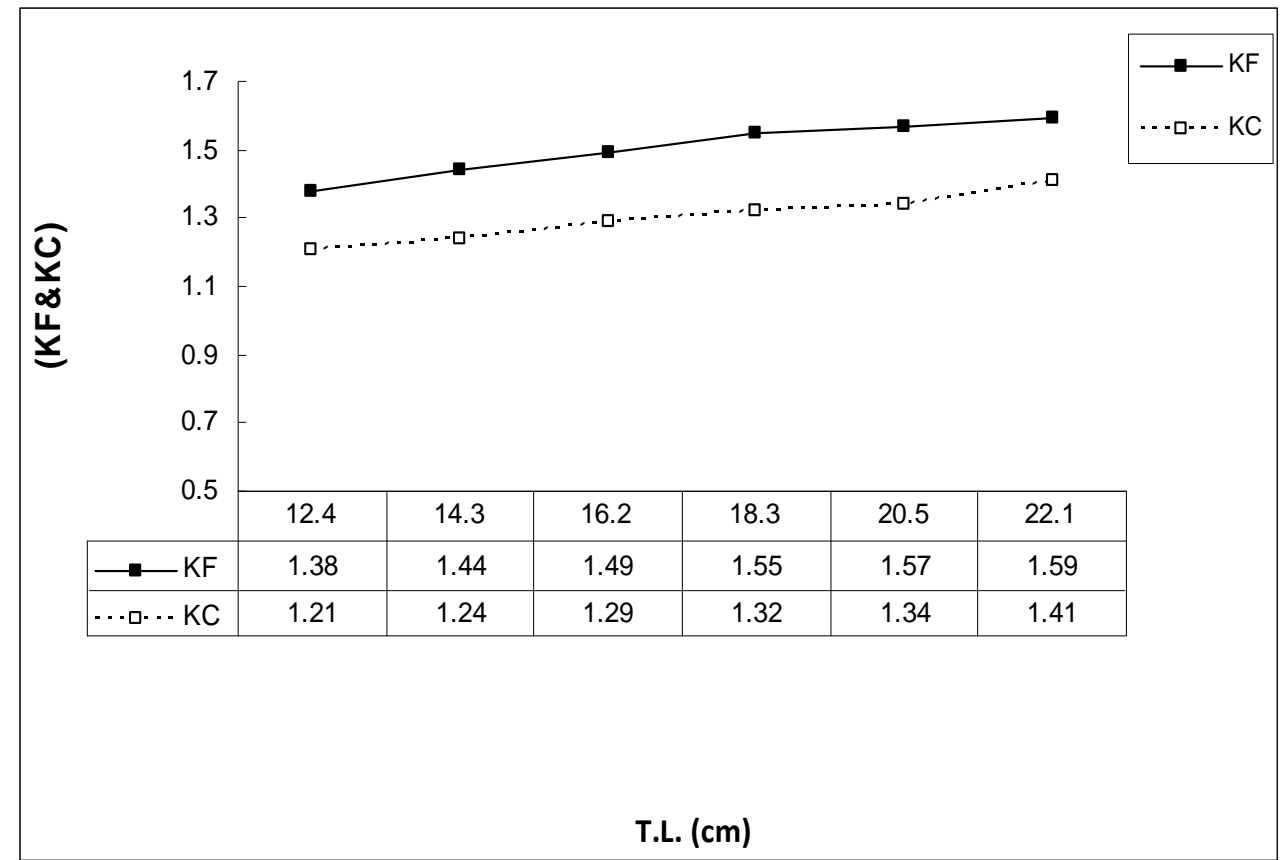

Fig. 2 The relationship between condition factor and length of L. mormyrus from Al-Haneah coast.

The monthly variations in condition factors $\mathrm{K}_{\mathrm{F}}$ and $\mathrm{K}_{\mathrm{C}}$ during the study period, March 2015 to February 2016 are shown in Fig. 3. During March $\mathrm{K}_{\mathrm{F}}$ and $\mathrm{K}_{\mathrm{C}}$ were 1.22 and 0.94 in order. Then they increased during April and recorded the highest values of 1.71 and 1.49 in May. High values were maintained during June, July and August. The monthly values then decreased gradually and reached a minimum of 1.27 and 0.98 .

\subsection{The Gonado-Somatic Index}

Changes in monthly Gonado-Somatic Indices (GSI) of males of L. mormyrus during the study period are shown in Fig. 4. Highest GSI were recorded in May (4.67\%), June (5.22\%), July (4.76\%) and August (5.81\%). A sharp decrease occurred in September $(1.41 \%)$. Low values were maintained during October $(0.96 \%)$ to February $(1.09 \%)$. The lowest value was during January $(0.74 \%)$. It is, therefore, concluded that the breeding season of males of this fish is May to August, i.e. summer.

The GSI for females (Fig. 5) recorded high values during May (6.76\%), June (7.61\%), July (8.88\%) and August $(9.79 \%)$. The GSI values then decreased sharply during September (3.50\%) and the following months and reached a minimum value of 1.72 during January. From this we can conclude that the breeding season of female L. mormyrus is May to August i.e. summer.

\subsection{Sex Ratio}

During all the study period the ratio of Males: Females was in favor of females (Table 2). Of the 224 fish examined during the study period 89 were males (39.7\%) and 135 were females (60.3\%), giving an overall ratio of 1: 1.52. The highest values were recorded during the breeding season, in May (69.2\%), June (64.7\%), July (65\%) and August (63\%).

\subsection{The Oocyte Diameter}

The oocyte diameter in March was $617 \pm 33.1$ (Table 3). It then increased during April $(722 \pm 34.5$ $\mu)$, May $(1,123 \pm 77.8 \mu)$, June $(1,333 \pm 105.6 \mu)$, July $(1,432 \pm 129.2 \mu)$ and reached the maximum in August $(1,511 \pm 143.3 \mu)$. The oocyte diameter then dropped to the lowest value of $379 \pm 25.3 \mu$ in October. During the period November, December and January the oocytes were either not present or too small to be measured. 
Reproductive Biology of the Striped Seabream Lithognathus mormyrus (Linnaeus, 1758) from Al Haneah Fishingsite, Mediterranean Sea, Eastern Libya

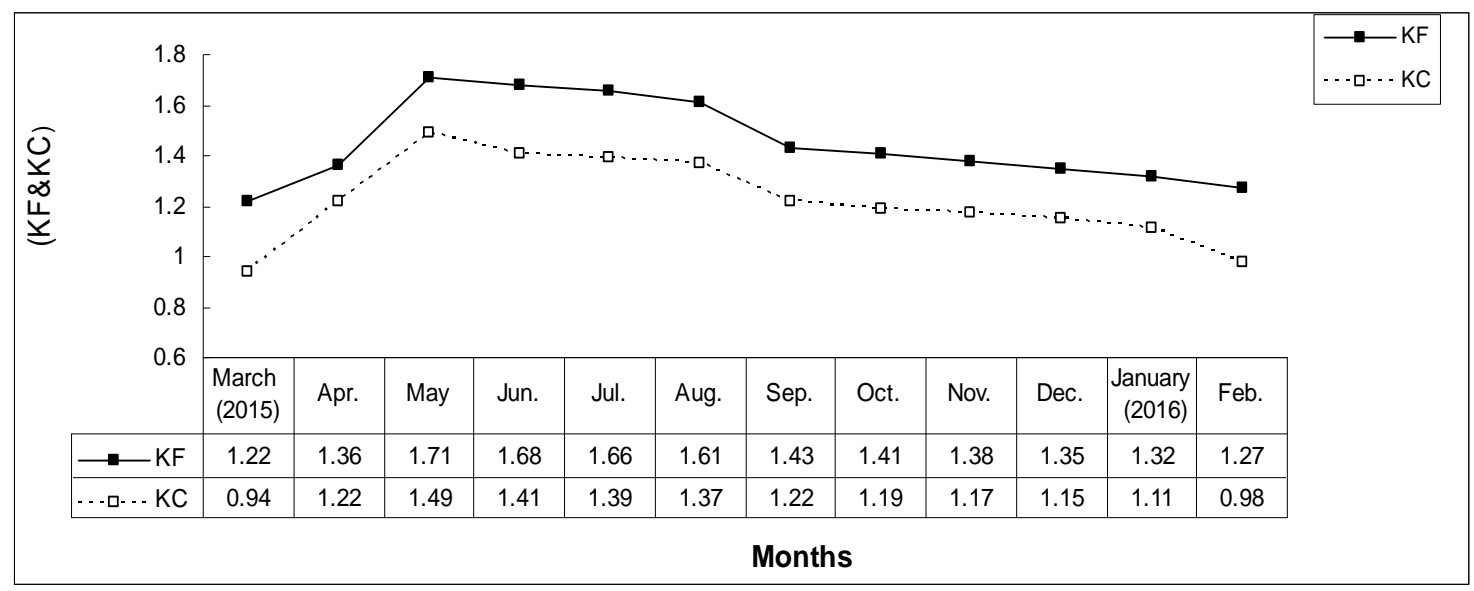

Fig. 3 Monthly variations of condition factors of $L$. mormyrus from Al-Haneah coast.

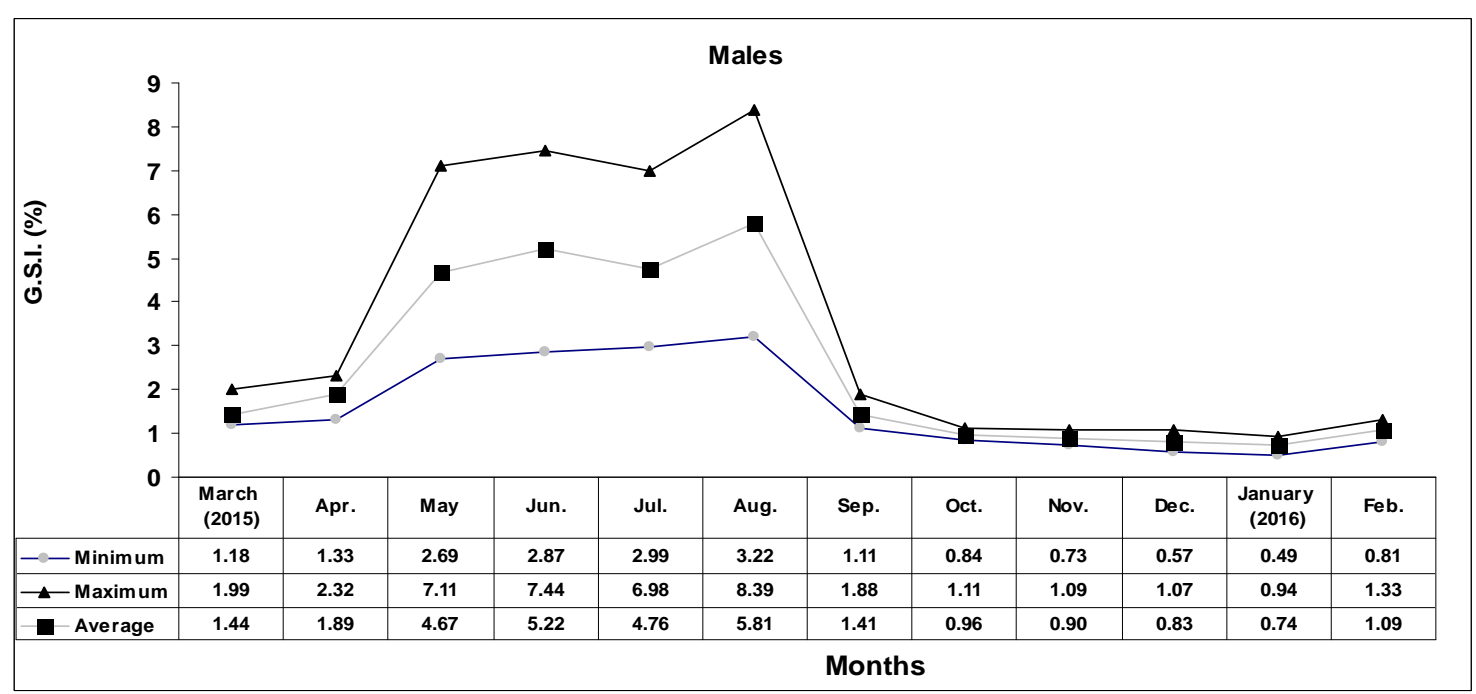

Fig. 4 Monthly variations of minimum, maximum and average gonado-somatic indices values of males $L$. mormyrus from El-Haneah coast.

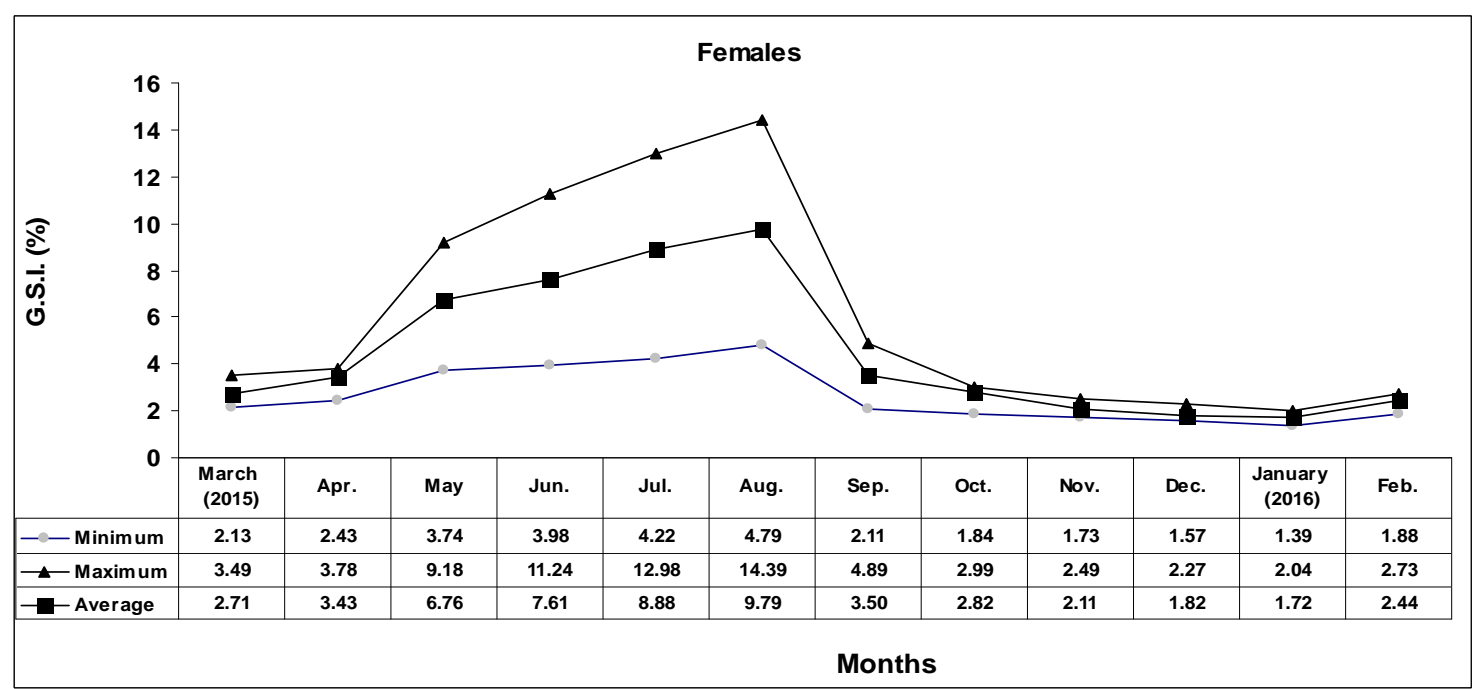

Fig. 5 Monthly variations of minimum, maximum and average gonado-somatic indices of females $L$. mormyrus from El-Haneah coast. 

from Al Haneah Fishingsite, Mediterranean Sea, Eastern Libya

Table 2 Monthly variations in sex ratio of $L$. mormyrus from Al-Haneah coast.

\begin{tabular}{|c|c|c|c|c|c|c|}
\hline \multirow{2}{*}{ Months } & \multirow{2}{*}{ No. of fish } & \multicolumn{2}{|c|}{ Males } & \multicolumn{2}{|c|}{ Females } & \multirow{2}{*}{-Sex ratio } \\
\hline & & No. & $\%$ & No. & $\%$ & \\
\hline March (2015) & 21 & 8 & 38.1 & 13 & 61.9 & $1: 1.63$ \\
\hline Apr. & 22 & 10 & 45.5 & 12 & 54.5 & $1: 1.20$ \\
\hline May & 13 & 4 & 30.8 & 9 & 69.2 & $1: 2.25$ \\
\hline Jun. & 17 & 6 & 35.3 & 11 & 64.7 & $1: 1.83$ \\
\hline Jul. & 20 & 7 & 35.0 & 13 & 65.0 & 1: 1.86 \\
\hline Aug. & 27 & 10 & 37.0 & 17 & 63.0 & $1: 1.70$ \\
\hline Sep. & 18 & 8 & 44.4 & 10 & 55.6 & 1: 1.25 \\
\hline Oct. & 17 & 6 & 35.3 & 11 & 64.7 & $1: 1.83$ \\
\hline Nov. & 21 & 10 & 47.6 & 11 & 52.4 & $1: 1.10$ \\
\hline Dec. & 18 & 8 & 44.4 & 10 & 55.6 & $1: 1.25$ \\
\hline January (2016) & 17 & 7 & 41.2 & 10 & 58.8 & $1: 1.43$ \\
\hline Feb. & 13 & 5 & 38.5 & 8 & 61.5 & 1: 1.60 \\
\hline Total & 224 & 89 & 39.7 & 135 & 60.3 & $1: 1.52$ \\
\hline
\end{tabular}

Table 3 Monthly variations of oocyte diameters $(\mu)$ of $L$. mormyrus from El-Hanea coast.

\begin{tabular}{|c|c|c|c|c|}
\hline \multirow[t]{2}{*}{ Months } & \multirow[t]{2}{*}{ Number of fish } & \multicolumn{3}{|c|}{ Egg Diameter $(\mu)$} \\
\hline & & Minimum & Maximum & Average \\
\hline March (2015) & 3 & 467 & 754 & $617 \pm 33.1$ \\
\hline Apr. & 5 & 477 & 956 & $722 \pm 34.5$ \\
\hline May & 6 & 995 & 1,237 & $1,123 \pm 77.8$ \\
\hline Jun. & 5 & 1,212 & 1,438 & $1,333 \pm 105.6$ \\
\hline Jul. & 7 & 1,310 & 1,578 & $1,432 \pm 129.2$ \\
\hline Aug. & 9 & 1,352 & 1,688 & $1,511 \pm 143.3$ \\
\hline Sep. & 3 & 488 & 588 & $533 \pm 40.8$ \\
\hline Oct. & 4 & 311 & 444 & $379 \pm 25.3$ \\
\hline Nov. & 11 & M & M & M \\
\hline Dec. & 10 & M & M & M \\
\hline January (2016) & 10 & M & M & M \\
\hline Feb. & 3 & 389 & 422 & $408 \pm 31.1$ \\
\hline Average & & & & $895 \pm 111.3$ \\
\hline
\end{tabular}

$\mathrm{M}=$ The eggs were either not present or were too small for their diameters to be measured.

During February the oocyte diameter was $(408 \pm 31.1$

$\mu)$. The average oocyte diameter for all the examined 45 fish was $895 \pm 111.3 \mu$.

\subsection{Maturity}

$11.2 \%$ and $8.2 \%$ of males and females L. mormyrus in order in the class length $11.5-13.4 \mathrm{~cm}$ were mature (Table 4). Percentage maturity for males and females increased in the following class ranges such that all males and females in the class ranges $19.5-21.4 \mathrm{~cm}$ and $21.5-23.4 \mathrm{~cm}$ in order were mature.

\subsection{Length at First Maturity}

Length at first maturity $\mathrm{L}_{50}$ is the length at which half the population is mature and the other half is not. For L. mormyrus $\mathrm{L}_{50}$ was found to be $14.15 \mathrm{~cm}$ for males (Fig. 6) and 14.45 for females (Fig. 7).

\subsection{Absolute and Relative Fecundity}

Overall average of absolute fecundity for the 45 examined fish was 4,342 \pm 557 egg per fish (Table 5). The overall average of relative fecundity was $234 \pm$ 181 egg per $\mathrm{cm}$. 

from Al Haneah Fishingsite, Mediterranean Sea, Eastern Libya

Table 4 The percentage of mature and immature fishes at different length ranges of $L$. mormyrus from Al-Haneah coast.

\begin{tabular}{|c|c|c|c|c|c|}
\hline \multicolumn{2}{|c|}{ Total length $(\mathrm{cm})$} & \multicolumn{2}{|c|}{ Males } & \multicolumn{2}{|c|}{ Females } \\
\hline Range & Average & $\%$ Immature & $\%$ Mature & $\%$ Immature & $\%$ Mature \\
\hline $11.5-13.4$ & 12.4 & 88.8 & 11.2 & 91.8 & 8.2 \\
\hline $13.5-15.4$ & 14.3 & 45.8 & 54.2 & 49.8 & 50.2 \\
\hline $15.5-17.4$ & 16.2 & 32.5 & 67.5 & 38.5 & 61.5 \\
\hline $17.5-19.4$ & 18.3 & 18.6 & 81.4 & 28.6 & 71.4 \\
\hline $19.5-21.4$ & 20.5 & - & 100 & 11.1 & 88.9 \\
\hline $21.5-23.4$ & 22.1 & _- & 100 & _ & 100 \\
\hline
\end{tabular}

Remarks: Data expressed as percentage, $\left(\_\right)$No fish in length group occurred.

Table 5 Relationship between fecundity and total body length $(\mathrm{cm})$ of $L$. mormyrus from El-Hanea coast.

\begin{tabular}{lllllll}
\hline Total length $(\mathrm{cm})$ & \multicolumn{3}{c}{ Absolute Fecundity } & Relative Fecundity \\
\hline Range & Average & No. fish & Minimum & Maximum & Average & TF/TL $(\mathrm{cm})$ \\
\hline $11.5-13.4$ & 12.4 & 6 & 655 & 876 & $754 \pm 73.8$ & 60 \\
$13.5-15.4$ & 14.3 & 8 & 812 & 1,324 & $1,099 \pm 73.8$ & 76 \\
$15.5-17.4$ & 16.2 & 10 & 1,439 & 2,148 & $1,876 \pm 89.6$ & 115 \\
$17.5-19.4$ & 18.3 & 5 & 2,777 & 6,546 & $4,765 \pm 133.5$ & 260 \\
$19.5-21.4$ & 20.5 & 8 & 5,434 & 10,987 & $8,119 \pm 173.9$ & 396 \\
$21.5-23.4$ & 22.1 & 8 & 7,431 & 11,678 & $10,987 \pm 214.1$ & 497 \\
Average & Total $=$ & 45 & & & $4,342 \pm 557$ & $234 \pm 181$ \\
\hline
\end{tabular}

TF: Total Fecundity.

TL: Total fish length in $\mathrm{cm}$.

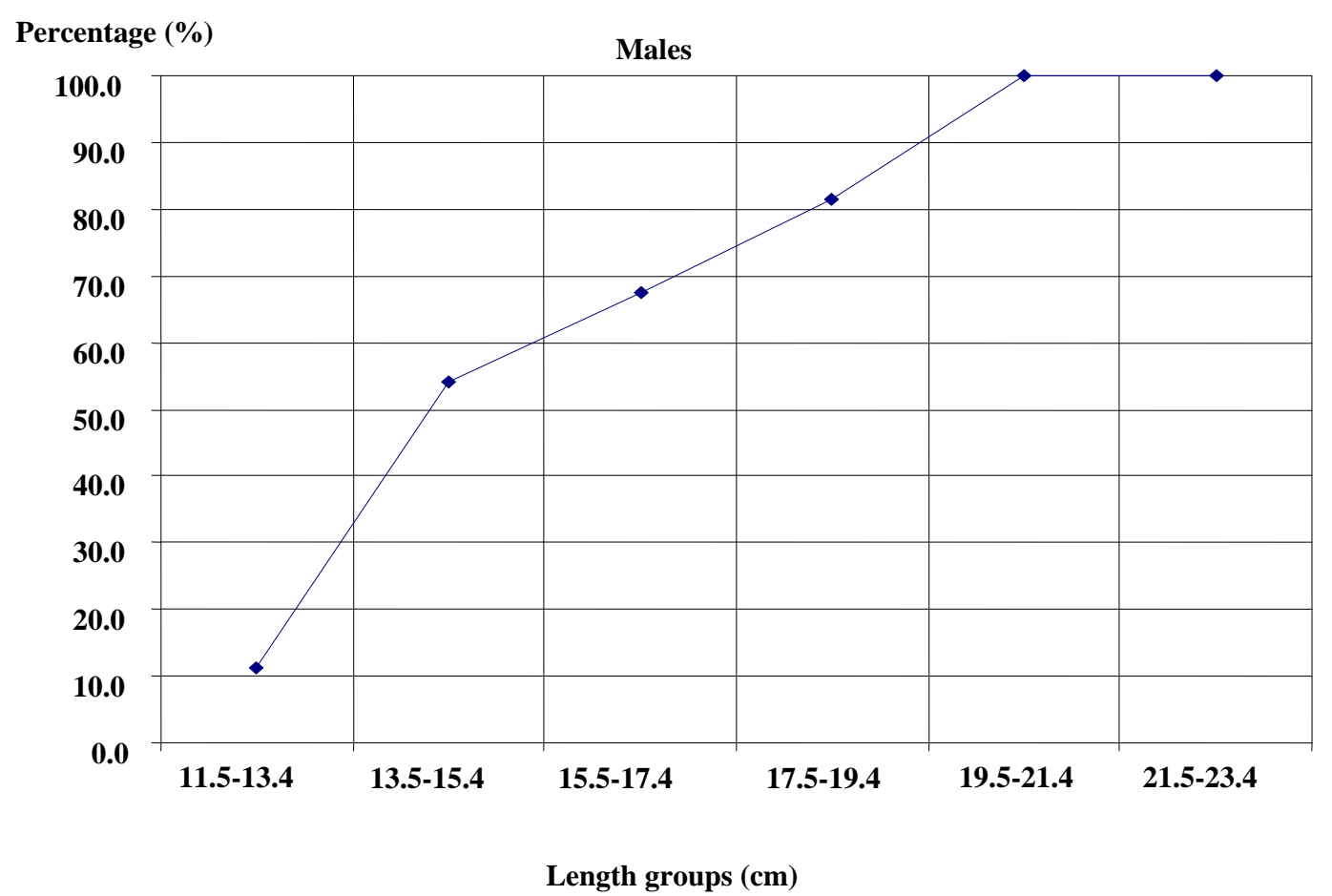

Fig. 6 Length at first maturity of males L. mormyrus from Al-Hanea coast. 


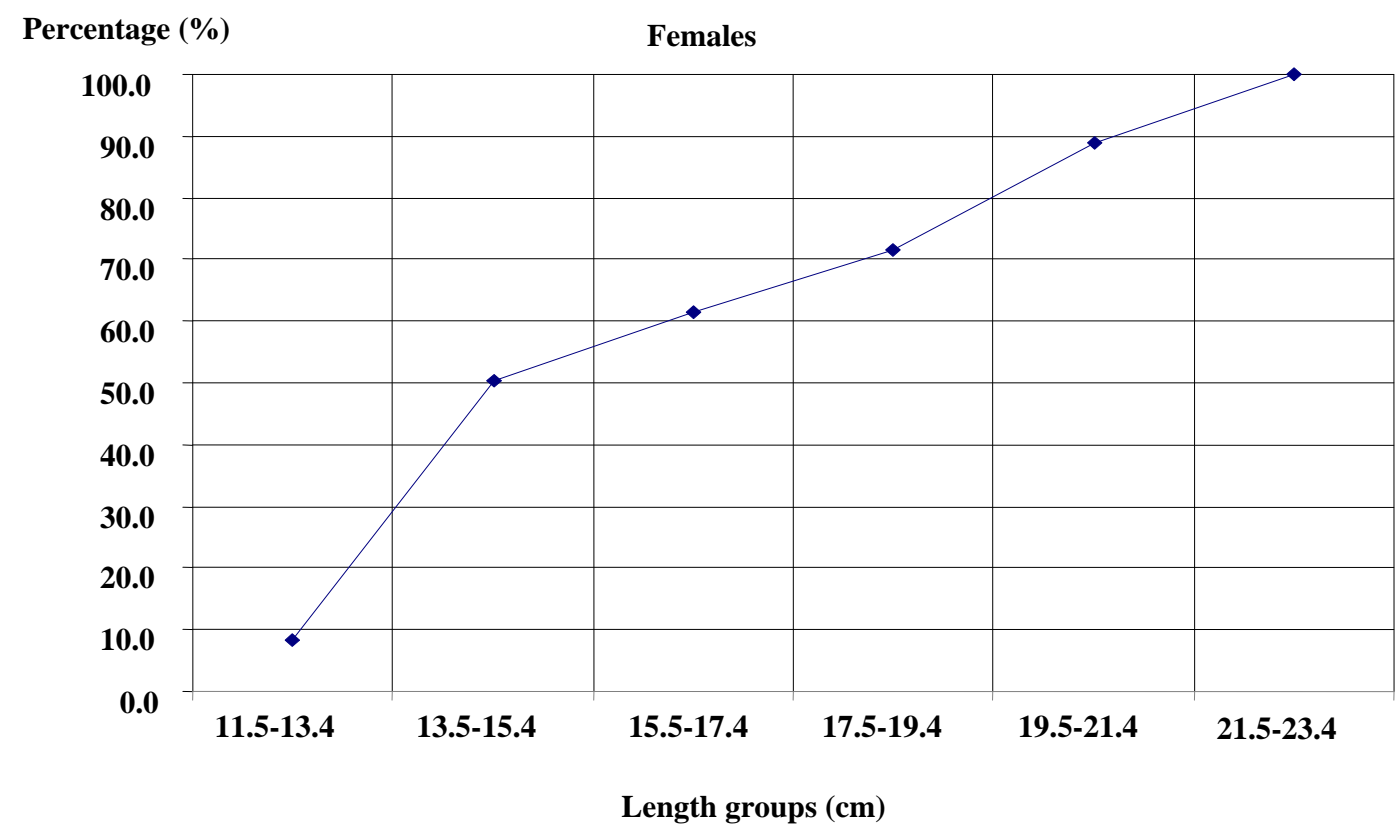

Fig. 7 Length at first maturity of females L. mormyrus from Al-Haneah coast.

Absolute fecundity increased with increasing fish length from $754 \pm 73.8$ egg per fish at the average total fish length of $12.4 \mathrm{~cm}$ to $10,987 \pm 214.1$ egg per fish at the average total length of $22.1 \mathrm{~cm}$.

The same trend was observed for the relative fecundity. It ranged from a minimum of 60 egg per centimeter at the average total length of $12.4 \mathrm{~cm}$ to 497 egg per centimeter at the average total length of $22.1 \mathrm{~cm}$.

\section{Discussion}

In the present study lengths of L. mormyrus studied ranged between $11.5 \mathrm{~cm}$ and $23.4 \mathrm{~cm}$. corresponding to the weights $24.5 \mathrm{gm}$ and $160.8 \mathrm{gm}$. Previous studies pointed that $L$. mormyrus can grow to a maximum length of about $55 \mathrm{~cm}$, with a weight of around $1 \mathrm{~kg}$, but the common size is $20-30 \mathrm{~cm}[12,13]$, it grows relatively fast during the first few years of life attaining approximately $50 \%$ of its maximum length during the second year [13-20].

In the present study the condition factors $\mathrm{K}_{\mathrm{F}}$ and $\mathrm{K}_{\mathrm{C}}$ increased with increasing fish length from 1.38 and 1.21 in order at the class range $11.5-13.4 \mathrm{~cm}$ to 1.59 and 1.41 at the class range $21.5-23.4 \mathrm{~cm}$. The larger the fish is the larger the condition factor. Matić-Skoko [21] studied growth of juvenile L. mormyrus from the DućeGlava, eastern Adriatic Sea. The obtained condition factor of 1.245 is close to the range of condition factors observed in the present study. Monthly variation of $\mathrm{K}_{\mathrm{F}}$ and $\mathrm{K}_{\mathrm{C}}$ was also determined in the present study. $\mathrm{K}_{\mathrm{F}}$ and $\mathrm{K}_{\mathrm{C}}$ recorded high values during May, June, July and August suggesting that summer is the breeding season of L. mormyrus. Same conclusion was also deduced from changes in monthly Gonado-Somatic Indices (GSI) of males and females. The highest GSI were recorded in May, June, July and August. A sharp decrease occurred in September. Low values were maintained during October to February. This was also supported by the observation that gravid females were encountered during summer. Previous studies agree that the reproductive season of $L$. mormyrus is summer [20,22-25] or spring and summer [26-30].

During all the study period the ratio of Males: Females was in favor to females. The overall ratio was 1: 1.52. Kraljević et al. reported the ratio for the 
western Istrian coastal waters as 1: 1.62. Ramos and Lorenzo et al. [20, 25], off the Canary islands reported 1: 0.85 and EMRE et al. [31], in the Beymelek Lagoon (Antalya, Turkey) reported 1: 1.84. L. mormyrus is protandric hermaphrodite [20, 25, 31, 32]. It starts its adult life as a male and later changes its sex to female at a length of about 21 to $30 \mathrm{~cm}$ (4-9 years) according to Bizsel et al. [13], or $25 \mathrm{~cm}$ to $35 \mathrm{~cm}$ according to the Malawi home page and Wikipedia, internet.

In the present study the oocyte diameter increased gradually through the months March, April, May, June, July and August where it reached the maximum value of $1,511 \pm 143.3 \mu$. The oocyte diameter then dropped to the lowest value of $379 \pm 25.3 \mu$ in October. During the period November, December and January the oocytes were either not present or too small to be measured. This indicated that the reproductive season of L. mormyrus was summer. Firat et al. [33], found that the average diameter of mature L. mormyrus egg was $0.71 \pm 0.1286 \mathrm{~mm}$. They also mentioned that generally, striped sea bream eggs have a diameter of 0.55-1.02 $\mathrm{mm}$. In the present study the average oocyte diameter of $L$. mormyrus was $895 \pm 111.3 \mu$.

In the present study in the class length $11.5-13.4 \mathrm{~cm}$, $11.2 \%$ and $8.2 \%$ of male and female L. mormyrus in order were mature. Length at first maturity, $\mathrm{L}_{50}$, is the length at which half the population is mature and the other half is not. In the present study $\mathrm{L}_{50}$ for $L$. mormyrus was found to be $14.15 \mathrm{~cm}$ for males and $14.45 \mathrm{~cm}$ for females. Sexual maturity for this species was reported by Suau, UNESCO, Kraljević et al. [28, 34], and Wikipedia, internet, to occur at a minimum length of $14.1 \mathrm{~cm}$ for males at age two. FAO [27], reported that this species matures at lengths of $13.3 \mathrm{~cm}$. Lorenzo et al. [20] and Kallianiotis et al. [35], reported that the lengths at $50 \%$ maturity for males and females were 16.2-20.7 cm and 19.0-24.6 cm consecutively. According to Monteiro et al. [36], (Algarve, south Portugal), the length at first maturity was similar for males and females and the value for both sexes combined was $16.08 \mathrm{~cm}$ corresponding to an age between 1 and 2 years.

In the present study the overall average absolute fecundity and relative fecundity were 4,342 $\pm 557 \mathrm{egg}$ per fish and $234 \pm 181 \mathrm{egg}$ per $\mathrm{cm}$ in order. Both absolute fecundity and relative fecundity increased with increasing fish length. We did not find any previous studies on fecundity of L. mormyrus.

\section{References}

[1] Linnaeus, 1758. "Lithognathus mormyrus-Linnaeus, 1758.” In Fish Base. Retrieved 2015.

[2] Bauchot, M. L., and Smith, J. L. B. 1985. "Sparidae in FAO Species Identification Sheets from Fishery Purposes." Western Indian Ocean Fishing Area 51 (4) (Fisher, W. and Bainchi, G.) eds. FAO. Rome.

[3] Guidetti, P. 2000. "Differences among Fish Assemblages Associated with Nearshore Posidonia Oceanica Seagrass Beds, Rocky-algal Reefs and Unvegetated Sand Habitats in the Adriatic Sea." Estuar. Cstl. Shelf Sci. 50: 515-29.

[4] Khamis, E. 2008. The Analysis of the Catch Trawling Net along Ben Gghazi, M. Sc, Thesis. Coast Fac. of Nat. Res. and Envi, 89, Omar El Mukhtar University.

[5] El-Ganainy, A. A. 2010. "Some Biological Aspects of the Filefish Setphanolepis diaspros (Family: Monacanthidae) from the Gulf of Suez, Egypt." Researcher 2 (10).

[6] Froese, R. 2006. "Cube Law, Condition Factor and Weight-length Relationships: History, Meta-analysis and Recommendations." J. Appl. Ichthyol. 22: 241-53, Journal Compilation 2006 Blackwell Verlag, Berlin, ISSN 0175-8659.

[7] Bagenal, T. B., and Tesch, F.W. 1978. Age and Growth. In: Methods for Assessment of Fish Production in Freshwaters, 101-36 (Bagenal, T., ed.). IBP Handbook No. 3. Blackwell Scientific Publications, London.

[8] Anderson, R. O., and Gutreuter, S. J. 1983. Length, Weight, and Associated Structural Indices. In: Fisheries Techniques (Eds. Nielsen, L. A. and Johnson, D. L.), 283-300. American Fisheries Society, Bethesda.

[9] Akter, H., Islam, M. R., and Belal Hossain, M. 2012. "Fecundity and Gonadosomatic Index (GSI) of Corsula, Rhinomugil corsula Hamilton, 1822 (Family: Mugilidae) from the Lower Meghna River Estuary, Bangladesh." Global Veterinaria 9 (2): 129-32, ISSN 1992-6197. (C) IDOSI Publications, 2012. DOI: 10.5829/idosi.gv.2012.9.2.6431.

[10] Bagenal, T. B. 1978. "Fish Fecundity and Its Relations with Stock and Recruitment." Rapp. P-V. Reum. Cons. Perm. Int. Explor. Mer. 164: 186-98. 

from Al Haneah Fishingsite, Mediterranean Sea, Eastern Libya

[11] Hossain, Y., Mosaddequr, R., and Elgorban, M. A. 2012. "Relationships between Body Size, Weight, Condition and Fecundity of the Threatened Fish Puntius ticto (Hamilton, 1822) in the Ganges River, Northwestern Bangladesh." Sains Malaysiana 41 (7): 803-14.

[12] Bauchot, M. L., and Hureau, J. C. 1990. Sparidae. In FAO Species Rome.

[13] Bizsel, C., Kara, M. H., Pollard, D., Yokes, B., Goren, M., and Francour, P. 2011. Lithognathus mormyrus. The IUCN Red List of Threatened Species 2011: e.T170160A6727018. Downloaded on 02 October 2015.

[14] Besseau, L., and Brusl-Sicard, S. 1991. Sex Inversion in a Protandric hermophrodite Model Lithognathus mormyrus L. (1758) (Teleostei: Sparidae): Histological Peculiarities, 95. In: Proceedings of the 4th International Symposium on the Reproductive Physiology of Fish (Eds. Scott, P. A., Sumpter, J. P., Kime, D. E. and Rolfe, M. S.). University of East Anglia, Norwich.

[15] Besseau, L., and Brusl-Sicard, S. 1995. "Plasticity of Gonad Development in Hermaphroditic Sparids: Ovotestis Ontogeny in Protandric Species, Lithognathus mormyrus." Env. Biol. of Fishes 43: 255-67.

[16] Kraljevic, M., Dulcùic, J., Pallaoro, A., Cetinic, P., and Jug-Dujakovic, J. 1995. "Sexual Maturation, Age and Growth of Striped Sea Bream, Lithognathus mormyrus L., on the Eastern Coast of the Adriatic Sea." J. Appl. Ichthyol. 11: 1-8.

[17] Kraljevic, M., Dulcùic, J., Cetinic, P., and Pallaoro, A. 1996. Age, Growth and Mortality of the Striped Sea Bream, Lithognathus mormyrus L., in the Northern Adriatic. Fisheries Research 28: 4361-70.

[18] Pajuelo, J. P., Lorenzo, J. M., Mendez, M., Coca, J., and Ramos, A. G. 2002. "Determination of Age and Growth of the Striped Seabream Lithognathus mormyrus (Sparidae) in the Canarian Archipelago by Otolith Readings and Backcalculation.” Sci. Mar. 66 (1): 27-32.

[19] Mann, B. Q., and van der Elst, R. P. 2000. Lithognathus mormyrus. In: Mann, B. Q. (ed.), Southern African Marine Linefish Status Reports. Special Publication No. 7 Oceanographic Research Institute, Durban.

[20] Lorenzo, J. M., Pajuelo, J. G., Méndez-Villamil, M., Coca, J., and Ramos, A. G. 2002. "Age, Growth, Reproduction and Mortality of the Striped Sea Bream, Lithognathus mormyrus (Pisces, Sparidae), off the Canary Islands (Central-East Atlantic).” J. Appl. Ichthyol. 18 (3): 204-9.

[21] Matić-Skoko, S., Josipa, F., Miro, K., and Jakov, D. 2007. "Growth of Juvenile Striped Seabream, Lithognathus mormyrus (Teleostei: Sparidae) in the Adriatic Sea." Institute of Oceanography and Fisheries, Meštrovićevo Šet. 63, P.O.Box. 500, 21000 Split, Croatia. Fax: +38521358650 .

[22] Bini, G. 1968. Atlante dei pesci delle coste Italiane. Vol.
IV. Osteiti. Mondo Sommerso Editrice.

[23] Tortonese, E. 1975. Osteichthyes (Pesci ossei), II. Fauna dÕ Italia, 11. Ed. Calderini, Bologna.

[24] Grubisùic, F. 1982. Ribe, rakoviisùkoljkejadrana. ITRO Naprijed, Zagreb-GRO Liburnija, Rijeka.

[25] Ramos, A. G. 2002. "Age, Growth, Reproduction and Mortality of the Striped Sea Bream, Lithognathus mormyrus (Pisces, Sparidae), off the Canary Islands (Central-East Atlantic)." Journal of Applied Ichthyology 18 (3): 204-9. DOI: 10.1046/j.1439-0426.2002.00318.x (Impact Factor: 0.87).

[26] Suau, P. 1970. Contribución al studio de la biologia de Lithognathus (= Pagellus) mormyrus L. (Pecesespáridos). Inv. Pesq. 34: 237-65.

[27] FAO. 1982. ConseilG.n.ral des Pches pour la M.diterran.e, Rapport de la premi.re Consultation Technique sur l'Evaluation des Stocks dans la M.diterran.e Centrale. FAO Rapp. P.ches 266, FAO, Rome.

[28] UNESCO. 1984/1986. "Fishes of the North-eastern Atlantic and the Mediterranean" (FNAM). UNESCO Publication. Edited by Whitehead, P. J. P., Bauchot, M.-L., Hureau, J.-C., Nielsen, J., and Tortonese, E..

[29] Erzini, K., Bentes, L., Lino, P. G., Riberio, J., Coelho, R., Monteiro, P., Correia, C., and Goncalves, J. M. S. 2001a. "Age and Growth of Seven Sparid Species of the South Coast of Portugal." Tenth European Congress on Ichthyology ECI X, Prague, Czech Republic.

[30] Erzini, K., Bentes, L., Lino, P. G., Riberio, J., Coelho, R., Monteiro, P., Correia, C., and Goncalves, J. M. S. 2001 b. Reproductive Aspects of Seven Sparid Species of the Southern Coast of Portugal (Algarve). Tenth European Congress on Ichthyology ECI X, Prague, Czech Republic.

[31] Emre, Y., İsmet, B., Cetin, S. D., Aytuğ, O., and Ozgur YEŞILCIMEN, H. 2010. "Age, Growth, Length-weight Relationship and Reproduction of the Striped Seabream (Lithognathus mormyrus L., 1758) (Sparidae) in the Beymelek Lagoon (Antalya, Turkey).” Turk. J. Zool. 34: 93-100 c TUBITTAK doi:10.3906/zoo-0808-13.

[32] Bailly, N. 2015. Lithognathus mormyrus (Linnaeus, 1758). In: Froese, R. and Pauly, D.. Editors. FishBase. Accessed through: World Register of Marine Species at http://www.marinespecies.org/aphia.php? $p=$ taxdetails\&id $=127055$ on 2015-04-29.

[33] Firat, K., Sahin, S., and Okan Kamac, H. 2005. EMBRYONIC AND LARVAL DEVELOPMENT OF STRIPED SEABREAM.

[34] Suau, P. 1970. "Contribuci.n al estudio de la biologiaLithognathus (= Pagellus) mormyrus L. especialmente de la sexualidad." Invest. Pesq. 1: 59-66.

[35] Kallianiotis, A., Michele, T., and Anna, A. 2005. "Age, Growth, Mortality, Reproduction and Feeding Habits of 
Reproductive Biology of the Striped Seabream Lithognathus mormyrus (Linnaeus, 1758) from Al Haneah Fishingsite, Mediterranean Sea, Eastern Libya

the Striped Seabream, Lithognathus mormyrus (Pisces: Sparidae) in the Coastal Waters of the Thracian Sea, Greece." Scientia Marina 69 (3): 391-404. doi:10.3989/scimar.2005.69n3391.

[36] Monteiro, P., Luis, B., Rui, C., Carla, C., Karim, E., Pedro, G. L., Joaquim, R., and Jorge, M. S. G. 2010. "Age and
Growth, Mortality and Reproduction of the Striped Sea Bream, Lithognathus mormyrus Linnaeus 1758, from the South Coast of Portugal (Algarve)." Marine Biology Research 6 (1): 53-65.

[37] L 1758. The Israeli Journal of Aquaculture-Bamidgeh 57 (2): 131-40. 